\title{
CONFLICT AND ITS MANIFESTATIONS IN ACHEBE'S "ARROW OF GOD"
}

\author{
Owen G. MORDAUNT
}

English Department

University of Nebraska at Omaha

Omaga, Nebraska 68182-0175

USA

\section{SUMMARY}

Mordaunt describes how the Nigerian author Chinua Achebe deals with the problem of personal conflict in his novel "Arrow of God".

The main character in this novel is Ezeulu, who is chief priest of the god Ulu, of the village of Umuaro. Ezeulu comes into conflict with himself in a quest to hold on to power despite his high age and the break-through of the British colonial administrators. Ezeulu wants to control both his people and the British administrators. Ezeulu believes the clan will silently follow him and the British will respect him. Hereto he sends his son to the white man's missionary school where the boy adopts the new religion and sacrileges his own. Ezeulu will not punish him despite the wishes of the clan.

Achebe's novel shows that men cannot fight societies' will and that the latter can bring a man to insanity.

KEYWORDS: English literature, Literature, Nigeria, Psychology.

As a foremost African novelist, Achebe has been of interest to several African literary critics, thus the plethora of works of criticism on his four novels, Things Fall Apart, Arrow of God, No longer at Ease, and AMan of the People. Among the best known critics are Obiechina, Bernth Lindfors, Abiola Irele, David Carrol, David Cook, G.D. Killam, G-C. M. Mutiso, Peter Nazareth, 
Emmanuel Ngara, Benedict Chiaka Njoku, Eustace Palmer, and Shatto Gakwandi. Critics have looked at setting, style, conflict and characterization in terms of cultural, political and religious considerations. The internal conflict of central characters, one of Achebe's achievements, lies in his skill at the externalizing the conflict of his characters. To measure the quality of Achebe's accomplishments, I will examine his second novel Arrow of God in some detail with reference to the central character.

Arrow of God is not so much concerned with the society as with Ezeulu himself. He is established in a closely-knit society, and it is in his relationship with this community and also with other elements or factors in this setting that we are able to comprehend the problem that he is faced with. Ezeulu and his culture are one. There exists a genuine struggle between Ezeulu and his rivals in his own tribe, the British administrators and Christian missionaries. But the struggle does not get down to the root of the matter: Arrow of God is not so much concerned with inter-tribal conflict, but with the chief priest of Ulu who is in conflict with himself. Whatever external forces are brought to bear upon his life are there only as objectifications of what actually goes on inside him.

The story is set in an Igbo village in Nigeria during a time when colonial influence-British colonial rule and the inroads of missionary activity- is beginning to be felt. This is the milieu in which we find the main character, Ezeulu, the chief priest of Ulu, the most powerful god of his Umuaro people, and, therefore, he is designated a special status in the society. He is patt and parcel of this society, and it is difficult to study him apart from it. With such a rich and complex story, it is easy for the non-African reader to get lost in the forest of cultural verbiage and miss the focus of the story, thus interpreting it as a story whose main focus is village life as sugessted by the Times Literary Supplement (26). True, there does seem to be a preponderance of village life, but this is the setting in which the central figure expresses his character, it is in this role, that of interpreting to Umuaro the will of the god and performing the two most significant rituals in the life of the people-the festivals of the Pumpkin Leaves and the New Yam. Ezeulu, the intermediary, is half black and half white, thus bridging the spirit and the human world (151).

The novel opens with Ezeulu brooding over his eyesight "and that someday he would have to rely on someone else's eyes as his grandfather had done 
when his sight failed" (1). Such a feeling is not unnatural; many people think about future incapacitations, but this scene establishes the tone for the novel and unveils Ezeulu's internal conflict. The allusion here is that this impending blindness is a threat, for it will interfere with his ordering of religious festivals, and will even mean that his tribal influence will cease to be felt among his people if he fails to observe the progression of the moon. If his religious responsibility will be challenged, his political responsibility will be in danger. He endeavors to console himself by imagining that he is as fit "as any young man, or better because young men were no longer what they used to be" (1). This gesture is indicative of his desire to maintain a perpetual authority over his tribe; he realizes that old age is beginning to tell him, but this he repudiates.

In spite of all the tremendous power in his hands, he knows he depends on the supernatural forces whose ways nobody can understand; this perception renders him somewhat helpless. Even the choice of his successor is in the power of Ulu; therefore, his dependence on the deity is a threat to his authority. Ezeulu's authority can be asserted only when co-operation with the supernatural powers is established. Any thought which seeks to undermine his authority has grave psychological implications. Throughout the novel, we see him writing in anguish over his authority, haunted by fear that his power is in danger of being challenged. It is no wonder since he wields immense power over the year, the crops, and over the people, but "he named the day" and did not "choose" it, except for the feast of the pumpkin Leaves and for the New Yam feast. He regards himself merely as a "watchman":

His power was no more than the power of a child over a goat that was said to be his. As long as the goat was alive it was his; he would find it food and take care of it. But the day it was slaughtered he would know who the real owner was. No! the Chief Priest of Ulu was more than that. If he should refuse to name the day there would be no festival-no planting and no reaping. But could he refuse? No Chief Priest had ever refused. So it could not be done. He would not dare. (3)

Ezeulu is disconcerted by his thoughts "as though his enemy had spoken" (4). But then, toying with the word dare, he convinces himself that no person in Umuaro can face him and tell him that he, Ezeulu, "dare not". Obviously, Ezeulu is the type of character who will not give up the quest for solving his problem of authority; he will continue to probe, endeavoring to grapple with the situation. 
His mind still persisted in trying to look closely at the nature of his power. What was it if everybody knew that it would never be used? Better to say that it was not there, that it was no more than the power in the anus of the proud dog who tried to put out a furnace with his puny fart. (4)

According to Cook (18), the novel "searches into the limits of individual power in a system controlled by tradition," a situation that any traditionalist would be aware of, but Ezeulu refuses, in his mind, to be a mere puppet leader, who must execute his duties according to the dictates of his position. He has a conflict which he must deal with. That is why, later in the text, he loses his equanimity: he no longer is content to see himself as " merely a watchman" (3). He has of course assessed his situation in light of influences and changes brought to bear on his society. He, no doubt, is intrigued by the power of the white man, particularly the latter's use of the firearm to quell the civil war between Umuaro and Okperi.

In his dilemma, Ezeulu sends his son Oduche to the white man's region on the assumption that the white man has come " with great power and conquest, it was necessary that some people should learn the ways of his own deity...[but] He also wanted to learn the white man's wisdom..." (47). Ezeulu has an ulterior motive for sending his son to the mission school; it is really for personal gain, not for the good of the society of which he is a part. What motivates him is the deep-seated fear of what he lacks: power. He indirectly exercises his shrewdness in this particular instance. He is at this point not aware of or does not even foresee any repercussion in making a decision contrary to the sanction of his people. In this way, he puts one foot in the new culture.

His people are of course vehemently opposed to this deliberate step because he is operating outside the collective solidarity of people who share common customs and beliefs and world view. This act brings him into conflict with his friend and confidant, Akuebue, but Ezeulu puts self-interest before the traditional group and its interests, thus Akuebue's warning:

"But if you send your son to join strangers in desecrating the land you will be alone. You may go and mark it on the wall to remind you that I said so". (151) 
These are strong words, but Ezeulu will not heed even the admonition of a close and wise friend.

"Who is to say when the land of Umuaro has been desecrated, you or I?" Ezeulu's mouth was shaped with haughty indifference. "As for being alone, do you think that it should be as familiar to me now as are dead bodies to the earth? My friend, don't make me laugh." (151)

Cook (18) notes that "Ezeulu's isolation, whether we see it ordained or self-appointed, is particular to himself and sets him apart." His stubborness sets him apart as an individualist in a communal structure. Ezeulu encourages his son to attend the church school even though he himself is apprehensive about it. He is indeed a person who is perceptive about what is going on around him; therefore, he tells Oduche that the world is changing, a phenomenon that intensifies his conflict, thus the purpose for sending his son to join the missionaries to be his "eye" there. If there is "nothing in it" , Oduche will return; if on the other hand , there is "something there", Oduche will " bring home his [Ezeulu's] share". $(50,51)$. At the back of Ezeulu's mind is the thought that not befriending the white man may bring regret in the future instead of paying dividents. Achebe, obviously, has created a character who is struggling to have it both ways-he has the perceptions and heart of an intelligent risk-taker in ideas. Oduche's mother's displeasure at her husband's sacrificing of her son to the white man's religion meets with utter defiance on his part, however persistently she endeavours to reason with him. He has the last word, believing that his decision is right.

"How does it concern you what I do with my sons? You say you do not want Oduche to follow strange ways. Do you not know that in a great man's household there must be people who follow all kinds of strange ways? There must be good people and bad people, honest workers and thieves, peace-makers and destroyers; that is the mark of a great obi. In such a place whatever music you beat on your drum there is somebody who can dance to it". (51)

Achebe is indicating here that Ezeulu has become marginal in propounding ideas completely at variance with his culture's norms, necessitated by the predicament in which he finds himself. As people belonging to a traditional society, Oduce's mother and other members of his family, no doubt, have a clear understanding of what societal expectations are for different members 
of the clan. Ezeulu's family does not share the secrets of his worship or when he is in consultation with his god, but they know what should constitute the behavior expected of people in high places, particularly that of a chief priest, a religious leader, who is the official mediator between the people and the deity. Ezeulu's family is both concerned and embarrassed, but they are powerless to deter the almost demented head of the family from turning a deaf ear to them and to society. His recalcitrance inevitably alienates him from the closest to him, his family.

A complication in the plot develops when Ezeulu's plan backfires; this is when Oduche, in the eye's of the community, commits sacrilege: the imprisoning of the sacred python. Oduche at this point has become a zealous convert to the new religion. His father is intensely disturbed, as this confirms the potency of the white man's religion since it enters the boy's head and heart. The vehement struggle of the sacred python in the box prison could be interpreted as symbolizing the internal turmoil that Ezeulu is experiencing. Ezeulu's desire is to maintain his authority and to assert it- an attempt to escape reality. What Achebe has accomplished here is the delineation of a character whose apparent craftiness has relegated him to a situation where he is living an inauthentic life, in alienation with himself, and, therefore, estranged to the community to which he belongs, and even to the god whose will he pretends to know. He is living in a constant state of anxiety over his waning control, but he does not fully realize the extent of his condition. The odds are against him so that he is impotent to direct the conduct of the people of Umuaro. The apex of his conflict is reached when he refuses to eat the holy yams, thus bringing his vengeance upon all his people; even the innocent, those who are helpless, have to suffer.

The cultural clash, the domestic contention, and other problems and forces serve to externalize the conflict which is gnawing at the chief priest's innermost being. His household is divided; his sons no longer show the traditional respect due to a father, and his wives are at loggerheads with one another. Oduche has become the source of division, as well as Nwafu, the favorite son whom Ezeulu assumes will be Ulu's choice successor to the priesthood. Ezeulu's impotence at restoring order to his own household suggests an inability at unifying the people of Umuaro and Okperi? He fails at unification but refuses to admit defeat. At the meeting of the elders concerning the Umuaro-Okperi land dispute, what he says is futile. He has 
lost all support; the people side with Nwaka whose harangue of Ezeulu's speech meets with their approval. Nwaka inevitably becomes the voice of the tribe since the chief priest's words no longer carry any weight.

The long uproar that followed was largely of appropriation. Nwaka had totally destroyed Ezeulu's speech...Speaker after speaker rose and spoke to the assembly until it was clear that all six villages stood behind Nwaka. $(18,19)$

Nwaka is a rival of Ezeulu's and of course a personal enemy, a man of high standing in the community and a friend of Ezidmili, the chief priest of Edemili, the oldest deity whose conflict with Ulu is chronic. This aspect of the story includes an aspect of the conflict in the story which involves the deities. According to Palmer (88)

...the religious conflict intensifies the conflict within the traditional society itself...The conflict is really a struggle for authority within the clan, starting as a struggle for supremacy between the chief priests of two deities, Ezidmili, the chief priest of Edemili, and Ezeulu, the chief priest of Ulu, the main clan deity. Since Ezidemili dares not openly, he hides behind Nwaka the most powerful and wealthiest layman, one of the three surviving members who have taken all the titles of the clan. Nwaka comes from the largest village, Umunneora, and therefore naturally thinks that the leadership of the clan ought to be his. Hence a struggle for political battle, with Nwaka and Ezeulu as protagonists.

Ulu cannot stand a chance in the face of such circumstances. But it is Ezeulu himself who defies Ulu by his unscrupulous actions. His suspected dealings with the white man add to Ezidemili's fury when Oduche, the son of the 'sell-out', imprisons the sacred python. It is in connection with the clash between Okperi and Umuaro that Nwaka makes his voice heard. The chief priest of Ulu was himself embroiled in this acute affair and sided with the white man in favor of Okperi. All these cultural collisions are brought to light in the conflict between Ezeulu and Nwaka; they accumulate with such momentum that Ezeulu resorts to self- isolation, refusing any advice or assistance. We have seen how he has refused to heed his friend Akuebue's advice. Later on, village elders make representations to Ezeulu in a bid to persuade him to put the interests of the clan first. Some elders endeavor to remind him of his responsibility to the "Ezeulu," said Anichebe Udeozo. 
"We know that such a thing has never been done before but never before has the white man taken the Chief Priest away. These are not the times we used to know and we must meet them as they come or he rolled in the dust. I want you to look round this room and tell me what you see. Do you think there is another Umuaro outside this hut now?"

"No, you are Umuaro," said Ezeulu.

"Yes, we are Umuaro. Therefore listen to what I am going to say. Umuaro is now asking you to go and eat those remaining yams today and name the day of the harvest. Do you hear me well? I said go and eat those yams today, not tomorrow; and if Ulu says we have committed an abomination let it be on the heads of the ten of us here. You will be free because we have set you to it, and the person who sets a child to catch a shrew should also find him water to wash the odor from his hand. We shall find you the water. Umuaro, have I spoken well?"

"You have said everything. we shall take the punishment."

"Leaders of Umuaro do not say that I am treating your words with contempt; it is not my wish to do so. But you cannot say: do what is not done and we will take the blame. I am the Chief Priest of Ulu and what I have told you is his will not mine...But this is not my doing. The gods sometimes use us as a whip." (237-238)

Ezeulu is requested by the elders to go back to Ulu to ask him how they might appease him. The chief priest consults the deity but actually does not hear what the god is saying. Instead, he is so consumed by introspection that he is distracted by the ringing of the bell of Oduche's mission school. This is serious indeed; whatever Ezeulu feels or does affects the clan. The confusion he is in is not only personal but social as well. His refusal to eat the yams because he believes he is the only one enlightened by the deity and the only one who is in power to make decisions on behalf of the people is partly a pretext to wreak vengeance on the people. The reader is aware of the fact that, on account of the white man's interference in traditional African affairs, disorder has set in; the imprisonment of Ezeulu means that he is not able to execute his traditional responsibilities according to schedule. The tragedy of Umuaro is hence reflected in the tragedy of Ezeulu. What he experiences is also Umuaro's experience-his personal sufferings, and so on, as the representative of the wider community for which he is responsible. When we see him as a 
demented high priest at the end of the novel, it is clear that the society itself is in confusion; the former traditional solidarity has been broken. Obiechina (85) makes some salient comments relevant to the functioning of the traditional set up:

Social and political institutions of the traditional society have perfected the art of exacting conformity from the individual and discouraging deviations and subversion of the common will. In all their workings, these institutions emphasize the primacy of the group over the individuals who compose it. The careers of important characters like Okwonkwo (Things Fall Apart), Ezeulu (Arrow of god), and Araba (Danda) illustrate this primacy of the society over the individual. All of them are shown to be powerful, in their communities, the primacy of the latter is soon established. In the cases of Ezeulu and Araba, it is shown that the individual cannot find fulfillment outside the protective wing of his community. Ostracism is the dreaded, because it is the most effective, of all penal sanctions of the traditional society. It is at the most critical period that the missionaries, the chief priest's religious rivals, step in to exploit the situation. To them the disastrous condition of Umuaro is the wcrk of Yahweh, and consequently they take every advantage of a situation which has already deteriorated. Ezeulu's pride has precipitated destruction, not only to himself and the people but also to their religion and culture. The song of extermination which he referred to earlier in the novel has been fulfilled:

"It is saying: Leave your yam, leave your cocoyam and come to church. That is what Udoche says."

"Yes," said Ezeulu thoughtfully. "It tells them to leave their yam and their cocoyam, does it? The it is the song of extermination." (47)

...the news spread that anyone who did not want to wait and see all his harvest ruined could take his offering to the god of the Christians who claimed to have power to protect such a person from the anger Ulu...there was no more laughter left in the people. (246)

In his extremity many an Umuaro man had sent his son with a yam or two to offer to the new religion and bring back the promised immunity [i.e. protection from Ulu's wrath] Thereafter, any yam that was harvested in the man's field was harvested in the name of the son. (262) 
"Paradoxically," as Palmer (98) aptly puts it, "Ezeulu, who should have been the champion of his people's faith, becomes the agent of destruction." The part played by the colonial officers in the struggle for Ezeulu's authority is not that of rivals. How could they want to appoint him paramount chief if they were his rivals? The decision to appoint him paramount chief is consistent with the plan of the British to develop a system of indirect rule based on native institutions. Ezeulu is virtually the most likely candidate for this position. The white man has no regard for the traditional culture of Umuaro, and this signified by Ezeulu's rejection of a warrant chieftaincy. Obviously, Winterbottom has chosen Ezeulu because he believes that the latter has supported the colonial government over the Umuaro-Okperi land problem. Winterbottom does not care to investigate the chief priest's real motives for befriending him. Even Ezeulu's position as chief priest does not make that much difference to the British. They are not interested in his authority, for they are concerned with the execution of their colonial duties for colonial ends. The solidarity of the people of the villages means nothing to them as long as the natives do not fight among themselves and thus endanger the interests of the colonial authorities in England. The inroads of the white man is inevitable, but they do help the reader to see the intensity of Ezeulu's conflict; they are as ineluctable as the manifestations of old age gradually creeping into the chief priest's life.

The lengthy detention of Ezeulu by a British officer gives Ezeulu time to contemplate his revenge on his people because they have accused him of befriending the white man and betraying them (181). When he returns home, he receives a hero's welcome, and this calms him, but when his god visits him, "his thoughts of reconciliation are blunted" (Palmer 75).

Besides his lack of security, self-interest, and so on, what else can Ezeulu's action be attributed to? Obviously the hand of fate has inflicted him with a touch of insanity, and there is enough evidence in the text to support this. According to Palmer (94), the theme of madness pervades the novel, thus reinforcing the idea that the insanity, which becomes more intense as a result of Obika's death, is the climax of a progression. Without this realization on the part of the reader, Ezeulu's inflexibility in his decision to free his people from the bondage of starvation would seem strange. 
"Perhaps Akuebue was the only man in Umuaro who knew that Ezeulu was not deliberately punishing the six villages as some people thought. He knew that the Chief Priest was helpless; that a thing greater than nte had been caught in nte's trap" (250). During Akuebue's earlier encounter with Ezeulu, we are informed that what Ezeulu said "made him afraid and uneasy like one who encounters a madman laughing on a solitary path" (148). Akuebue suspects Ezeulu's madness. Interestingly enough, his mother was mad; Obika, Ezeulu's pampered son, is alluded to as mad, and Moses Unachukwa refers to madness in the family. Moreover, Nwaka maintains that Ezeulu's madness is inherited from his mother (198). Palmer (95) notes that "Achebe must have strewn so many references to madness in the text because he wanted us to believe that this is at least partly the cause of Ezeulu's otherwise inexplicable course of conduct."

But can Ezeulu's tragedy be attributable only to insanity? It is strange that in the end he is destroyed by the god whose directions he claims he accepts without any doubt. Akuebue believes that Ezeulu, even though proud and recalcitrant, would not falsify the decision of the god, but Ogbuefi Ofoka, on the other hand, is convinced that " a priest like Ezeulu leads a god to ruin himself." Akuebue responds by saying that "perhaps a god like Ulu leads a priest to ruin himself" (243). When Obika is killed, Ezeulu feels that Ulu has forsaken him. However, instead of blaming Ulu, we have to look closely at Ezeulu's own actions, which are responsible for his tragedy.

Clearly, during his imprisonment, which occurred some time prior to his divining the will of Ulu, Ezeulu made up his mind never to look for the new moon. When he does hear Ulu's voice, "his plan of revenge, a purely personal one caused largely by private pique, is already formed" (Palmer 98). Ezeulu is so bound up by his own thoughts that he does not hear what Ulu is saying. What he says he hears is from his own cloudy mind. No wonder he assumes that he is merely "an arrow in the bow of his god" (219). To him everything that happens is attributable to Ulu: Oduche's imprisonment of the python-the boy could be an arrow in the god's hand; the white man and his religion-agents of the god $(219,220)$. Ezeulu, nevertheless, pays for stepping beyond the parameters set for him by the deity. It is a heavy price: the death of Obika. As far as the villagers were concerned, Ulu was their creation at a time when they formed a union as a protection against slave raids. Ulu replaced older village deities. To these people, the clan takes precedence over everything 
else; however, as Wren (94) points out, "the chief priest's divination of the will of the god has set a course that could only lead to the destruction of the clan-but for the intervention of the church." Ulu belongs to the people, communally, and is responsible for them. Therefore, all Ezeulu's actions are seen by the people as being sanctioned by the deity, actions that defy the clan. There evolves a definite conflict, and Ezeulu pays dearly for over-stepping the boundaries set for him by Ulu. He is driven to madness. Wren (95) notes: "ulu's choice was between the clan and the priest...Ulu chose the clan, as it was his nature to do." In the end the people of Umuaro see the outcome of all that has transpired. 


\section{WORKS CITED}

Achebe, Chinua., Arrow of ged. New York: Anchor Books, 1969.

Carrol, David., ChinuaAchebe. London: Macmillan, 1980.

Cook, David., African Literature. A Critical View. Bristol: Longman, 1977.

Gakwandi, Shatto Arthur., The novel and Contemporary Experience in Africa. New York: Africana Publishing Company, 1980.

Irele, Abiola., "Chinua Achebe: the tragic conflict in his novels." Introduction to African Literature. Ed. Ulli Beier. London: Longman, 1979.

Killam, G.D., The novels of Chinua Achebe. New York: Africana Publishing Corporation, 1969.

Lindfors, Bernth., "The palm oil with which Achebe's words are eaten." African Literature Today. New York: Heinemann, 1972.

Mutiso, G-C. M., Socio-political Thought in African Literature: Weusi? New York: Barnes and Noble, 1974.

Nazareth, Peter. AnAfrican View of Literature. Evanston, Ill: Northwestem Univ. Press, 1974.

Ngara, Emmanuel. Stylistic Criticism and the African Novel. London: Heinemann, 1982.

Njoku, Benedict Chiaka. The four Novels of Chinua Achebe: A Critical Study. New York: Peter Lang, 1984.

Obiechina, Emmanuel. Culture. Tradition and Seciety in the West African Novel. Cambridge: Cambridge Univ. Press, 1975.

Palmer, Eustache. The Growth of the African Novel. London: Heinemann, 1979.

Times Literary Supplement (26 March 1964) : 249. 